\title{
The Management and Associated Costs of Rearing Heifers on UK Dairy Farms from Weaning to Conception
}

\author{
Alana C. Boulton, Jonathan Rushton, D. Claire Wathes \\ Department of Production and Population Health, Royal Veterinary College, North Mymms, UK \\ Email: dcwathes@rvc.ac.uk
}

Received 3 June 2015; accepted 6 July 2015; published 9 July 2015

Copyright (C) 2015 by authors and Scientific Research Publishing Inc.

This work is licensed under the Creative Commons Attribution International License (CC BY). http://creativecommons.org/licenses/by/4.0/

(c) (i) Open Access

\begin{abstract}
Dairy heifers only start to produce a return on investment at first calving. The length of the nonproductive rearing period is largely governed by farmer decisions on plane of nutrition and reproduction management. Primary data were collected from 101 dairy farms and a cost analysis workbook developed to calculate individual inputs in each of three periods to determine which management decisions and farm factors have the greatest influence on the total costs associated with rearing. This paper covers weaning until conception. Heifers were weaned at $62 \mathrm{~d}$ (range 42 $112 \mathrm{~d}$ ) and conceived by $509 \mathrm{~d}$ (range 365 - $700 \mathrm{~d}$ ) giving an average weaning to conception period of $447 \pm 60 \mathrm{~d}$ (range 253 to $630 \mathrm{~d}$ ). The mean daily cost of rearing during this period was $€ 1.65$ (range $£ 0.75$ to $£ 2.97$ on different farms) giving a mean total cost of $£ 745.94$ per heifer (range $£ 295.32$ to $£ 1745.85)$. This large variation was mostly due to the duration, which was mainly determined by age at first breeding (mean 476 days, range 365 - $700 \mathrm{~d}$ ). The main contributors to total costs were feed $(35.6 \%)$, labour $(24.7 \%)$ and bedding $(8.9 \%)$. The variables most strongly associated with the total costs were age at conception, calving pattern and breed. A multivariable model predicted an increase in mean cost of $£ 2.26$ for each extra day in age at conception. The total cost was highest in herds with all year round calving, intermediate in multi-block and lowest in spring and autumn calving herds, with Friesian $x$ and Jersey herds having the lowest cost of rearing.
\end{abstract}

\section{Keywords}

Heifer, Cost Analysis, Conception, Sexed Semen

\section{Introduction}

Heifers are the future of the dairy herd and the management of their rearing is important if the herd is to be sus-

How to cite this paper: Boulton, A.C., Rushton, J. and Wathes, D.C. (2015) The Management and Associated Costs of Rearing Heifers on UK Dairy Farms from Weaning to Conception. Open Journal of Animal Sciences, 5, 294-308. 
tainable and heifer wastage reduced. A common aim is to breed replacement heifers by 15 months of age to achieve an age at first calving (AFC) of 24 months. This is generally considered the minimum at which animals are sufficiently grown to calve without difficulty and to achieve a good first lactation milk yield. In practice, few farms achieve an average AFC of 24 months, with mean values ranging globally from 26 to 31 months [1]. Keeping the AFC to 2 years reduces the cost of rearing replacements but requires a good standard of management to ensure an adequate growth rate. Farmers generally decide when to start serving animals based on either age or size (weight and/or height). A high conception rate is then essential to achieve a low AFC. Another key consideration is health. Poor health not only slows growth and reduces fertility, but $6.9 \%$ of heifers born on UK dairy farms die or are culled between 28 days and the start of breeding [1] [2]. This impacts on the economics as the cost of resource use up to the point of death has to be apportioned onto the cohort of surviving heifers.

The period from weaning to conception is one of great physiological change during which heifers reach sexual maturity. It is also the period of greatest absolute growth with $75 \%$ of frame growth occurring prior to the onset of puberty [3]. Feeding and nutrition also changes during this time as calves move onto a mostly forage based diet after weaning with some supplementary feeding of concentrates. Within the UK, heifers are typically managed in groups and either kept indoors in loose housing or at pasture, depending on farm policy and season of calving. Management of feeding is important as heifers often experience a growth check post weaning and at the beginning of their first grazing season [4]. Pre-pubertal growth is particularly important from 3 months of age as mammary development is three times faster than the body as a whole [5]. Rapid growth of the mammary fat pad and the mammary ducts occurs post-weaning and this growth continues until the completion of several oestrous cycles [6]-[8].

Some studies suggest that a high plane of nutrition that encourages an increased growth rate from weaning to puberty reduces the amount of mammary parenchymal growth and therefore first lactation yield [9]. However, rapid growth rate until 4 months of age was found to have no adverse effect on mammary development [10]. A meta-analysis conducted by Zanton and Heinrichs [11] on prepubertal average daily gain (ADG) of Holstein heifers showed that maximal first lactation yield was achieved with an ADG of 799 g/d with weight gain greater than this being associated with decreased milk production during first lactation. At the time of breeding, around 14 to 15 months of age, heifers should weigh $55 \%-60 \%$ of their mature body weight to reduce the risk of dystocia and to calve down at the correct height and weight at around 24 months of age [12]. Even within breeds mature BW can vary considerably according to selection policy so actual target weights should be based on those of the mature cows in the herd [13].

Puberty is the time at which reproduction first becomes possible and is dependent on a certain level of body fat and protein reserves being achieved. In large dairy breeds, heifers begin cycling at approximately $40 \%$ of mature body weight at around 9-11 months of age. Several factors have been shown to influence the age of onset of puberty including weight, body size, breed, season and plane of nutrition [14]. The age that heifers achieve puberty will influence when the heifer is bred for the first time which in turn affects the age at first calving (AFC) and length of the non-productive period. Brickell et al. [15] found a first service conception rate of $67 \%$ in a study of fertility in English nulliparous heifers compared with 57\% (range 40\% to 70\%) in the USA [16] and 64\% in Sweden [17]. In their study, Kuhn et al. [16] found the maximum conception rate in heifers aged 15 to 16 months and that conception rate decreased markedly with increasing age with a $13 \%$ drop in conception rate in heifers aged $\geq 26$ months. There is considerable variability between UK dairy farms in the way that heifer fertility is managed. Farmers often start by using artificial insemination (AI), perhaps for a fixed number of occasions, and then run remaining non-pregnant animals with a bull. Successful AI requires either good heat detection or use of oestrous synchronisation regimes [18]-[20]. At present there is increasing use of sexed semen on heifers in dairy herds, driven by welfare and economic concerns over the production of unwanted bull calves, although the likely success rates are approximately $70 \%$ to $80 \%$ of those achievable using unsexed semen [20] [21].

One of the biggest health concerns during this period is from parasitic helminths during the first grazing season. Evidence has shown that infection from gastrointestinal worms leads to substantial weight loss in rearing stock due to reduced dry matter (DM) intake and parasitic bronchitis [22]. Studies have shown that heifers not treated with either a topical worming treatment or deworming bolus prior to and after turnout have reduced ADG compared to treated heifers [23] [24]. Depending on the calving pattern of the farm, heifers can enter the milking herd without full immunity which can affect future production and fertility.

The period from weaning to conception is normally the longest development period for replacement heifers. It is also a time when management of heifers is greatly reduced due to a majority of farms moving their young 
stock to different holdings away from the home farm. The aim of this study was to examine the management and cost of rearing dairy heifers from weaning to conception on a sub-set of UK dairy farms.

\section{Materials and Methods}

\subsection{Farm Selection, Questionnaire and Data Collection}

A total of 102 dairy farms in England, Scotland and Wales were recruited via industry extension services, farm consultancy groups, social media platforms and private veterinary groups. Information on costs associated with the period from birth to weaning have been published previously [25]. This paper covers the development period from weaning to conception. Data from 101 dairy farms were analysed as one farm was a flying herd and therefore sold off all their heifers following weaning. The farms were visited from March through August 2013 during which an interview and questionnaire were undertaken by a single researcher (Royal Veterinary College Ethics and Welfare Committee number 2013 1199). The questionnaire was based on a comprehensive study of dairy calf and heifer rearing in Canada [26]. A total of 124 questions (46 closed and 78 open) were completed during the interview with 13 closed and 39 open questions covering the period from weaning to conception. Interviews took on average 60 minutes to complete (range 40 to 120 minutes) and included questions relating to labour, type and characteristics of heifer housing, the availability of solid feeds including both forage and grain mixtures, concentrates and by-products, details on turn-out and grazing, the transportation and movement of youngstock, monitoring of animals including growth rate, disease, vaccination and health treatments (worming) and breeding and fertility. Input costs and farm factors pertaining to this period were also recorded.

\subsection{Calculation and Analysis of Input Costs}

To calculate the time spent in the period from weaning to conception the length of gestation was subtracted from the average AFC provided by the farmer to give the average age at conception. The period of time that heifers spent in this development period was therefore the difference between the age at conception and age at weaning. The number of days for gestation was set at 274 days ( 9 months) and was based on the range of gestation lengths found in a study by Jousan et al. [27].

The cost of housing, including bedding and disinfection costs, was based on the duration that heifers spent in the housing unit, the stocking density, the size of the housing unit, the type of bedding used, the cost per tonne of bedding material, the frequency of mucking out and rebedding and the use of disinfection in the housing unit. For farms that used mats either in cubicles or in group housing the cost of the mat was apportioned to the heifer only once even if they moved onto a different housing unit that also utilized mats as bedding material.

Feed costs including those for forage, grain mixtures, supplements, concentrates and by-products were recorded. The age that particular feed types were offered to heifers were also documented as well as the price per tonne for the feed, the quantity fed per day ( $\mathrm{kg}$ of freshweight) and the duration of feeding (days). If the feed was provided ad libitum for a period of time then the expected daily intake of feed for the particular age as discussed in the literature was used to calculate cost. If a range of figures were given for quantity, price or duration, the average of the figures was used in the calculations.

Questions asked regarding turnout of heifers included whether or not heifers had access to pasture and under what basis they were turned out. Farmers were allowed up to three decision criteria for turn out. The month they were turned out and returned to their housing was recorded as was their weight and/or age. The type of pasture and water source heifers had access to and whether youngstock were subject to any human disturbance (e.g. train tracks, dog walkers, motorways) was also documented. Whether heifers were subject to disturbance was recorded as this might explain differences in disease incidence, time at grass and growth rate.

The cost of grazing per hectare included annual establishment costs which were based on a five year ley and included the cost of seed, fertilizer and chemicals, annual fertilizer costs, the opportunity cost of renting out the land for other uses and the cost of contractors. The cost of contractors included the cost of fertilizer application and the costs associated with completing three silage cuts (mowing, harvesting, bailing and wrapping). Fertilizer costs, establishment costs and contracting costs were obtained from The Agricultural Budgeting and Costing Book [28] and DairyCo grassland management improvement programme [29].

The total cost of movement and transportation of heifers post-weaning included the cost of the initial movement of youngstock to another holding, journeys to and from the farm each day to inspect stock and/or provide 
supplemental feed or medical treatment, and the return journey to the farm prior to calving. It was assumed that the replacement herd was inspected and/or fed once per day based on The Welfare of Farmed Animals (England) Regulations 2000 (S.I. 2000 No. 1870) Schedule 4, paragraphs 3 and 4. If the heifers were transported to a contract rearer for the duration of their time up to calving then only the initial and return journey were costed.

Health and disease treatment during this period included the cost of vaccination, worming and ectoparasite treatment and the cost of veterinary medicine. If a heifer was given a booster or annual vaccination only the costs of those administered during the time from weaning to conception were included in the results. If the cost of the treatment was unknown by the farmer, the cost of the product was obtained from an online veterinary pharmaceutical supplier along with recommended dosage. Many treatments require a current bodyweight in order to determine dosage: if the farmer did not record bodyweight then the predicted bodyweight of the heifer at the age of treatment was used in the calculations [30].

The total cost of breeding included the cost of the veterinarian or technician administering artificial insemination (AI) and pregnancy confirmation,the cost and number of straws used depending on the number of services per conception, whether sexed or conventional semen was used, the cost of any synchronization or oestrus inducement treatments and any reproductive management services (RMS). The cost of labour associated with reproduction if AI was performed by farm personnel was included in the cost of farm labour. If the number of services per conception and conception rate were not known, a $65 \%$ first service conception rate was applied to farms that did not use sexed semen and a $40 \%$ first service conception rate to farms that used sexed semen [20] [31]. Sexed semen was always taken to be the first semen used followed by conventional semen unless stated otherwise. The cost of keeping a bull on farm included the cost of purchase, depreciation and annual running costs which covered the expenses for food, housing and veterinary services. The cost of purchase was set at $£ 4500$ with a $£ 1200$ cull value based on 5 years of service. This resulted in a $£ 660$ annual depreciation cost. If only one bull was present on the farm, the cost was apportioned based on the number of heifers and cows he was required to service. If the bull was only used for the replacement herd then the costs of maintaining a bull on the farm was apportioned to heifers only.

The methodology used to calculate the cost of labour, building and equipment depreciation, electricity, free water consumption and slurry storage and soiled bedding costs are described in Boulton et al. [25]. With reference to slurry storage the volume of slurry produced per day per heifer was estimated at 7.0 litres/day up to 91 days of age, 20.0 litres/day aged $>91$ days to 395 days and 40.0 litres/day aged $>395$ days to conception.

\subsection{Statistical Analysis}

The costs of inputs were collated in Microsoft Office Excel 2010 with STATA v12.1 (StataCorp, College Station, Texas, USA) used for statistical analysis. The Shapiro-Wilk test was used to test for normality and the Breusch-Pagan/Cook Weisberg test for heteroskedacity. Associations between each of the farm factors and cost of rearing were tested using simple linear regression with analysis of variance (ANOVA) used to test for differences between the means of categorical variables. Continuous variables were categorized if the plot of residuals against each of the continuous predictor variables failed. Explanatory variables were assessed for collinearity, with a score of $>0.8$ indicating high correlation between two variables [32]. Variables with $p$-values $<0.2$ in the univariate analysis were included in a multivariable analysis using forward stepwise selection starting with the variable with the highest $\mathrm{F}$ statistic and lowest $p$-value from the univariable analysis. The results of the ANOVA were used to determine the fit of the model. Tests for interactions between variables were also conducted.

\section{Results}

The UK farms included in this study kept between 10 and 1200 milking cows. The majority of the farms (73) practiced an all year round (AYR) calving pattern, 14 were autumn calving (August to October), 5 spring calving (February to April) and 10 were classified as multi-block, having two distinctive calving periods with a break in between. They were mostly conventional enterprises, with 9 herds registered as organic. Heifers on the farms included in this study were weaned at $62 \pm 13 \mathrm{~d}$, range $42-112 \mathrm{~d}$ [25]. The mean age at conception was 509 days, range 365 - 700. The length of the period from weaning to conception was $447 \mathrm{~d}$, range 253 - $630 \mathrm{~d}$. The contribution of each of the input costs to the total cost from weaning to conception is summarized in Table 1 and Figure 1. 


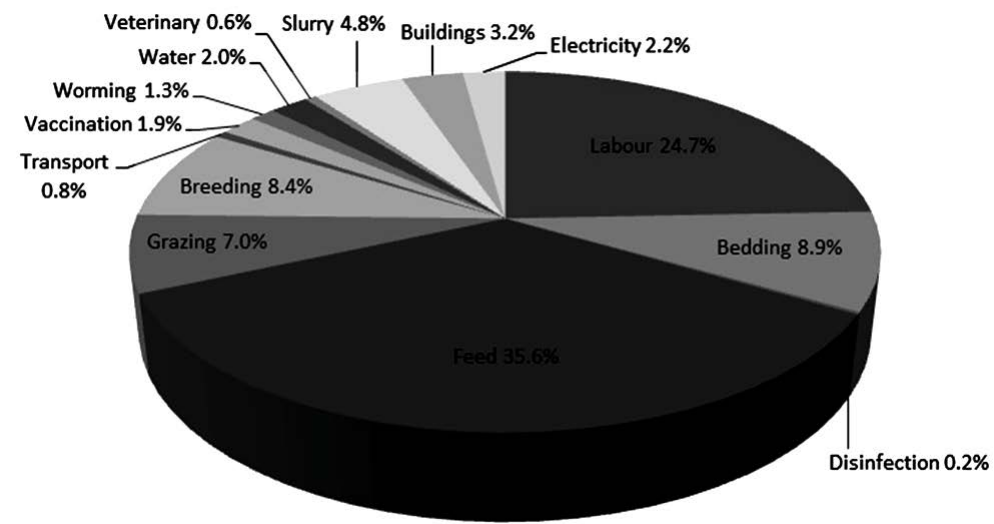

Figure 1. Contribution of input costs to total cost of rearing from weaning to conception.

Table 1. Summary data of the contribution of each of the costs assessed to the total cost per farm from weaning to conception.

\begin{tabular}{|c|c|c|c|c|}
\hline \multirow{2}{*}{ Input } & \multicolumn{4}{|c|}{$\%$ Contribution to total cost of weaning } \\
\hline & $\mathrm{n}^{\mathrm{a}}$ & Mean & Range & Median \\
\hline Labour & 101 & $24.7 \pm 11.9$ & $7.3-72.1$ & 22.2 \\
\hline Bedding & 101 & $8.9 \pm 5.2$ & $0.5-21.4$ & 8.1 \\
\hline Disinfection & 66 & $0.2 \pm 0.02$ & $0-3.9$ & 0.03 \\
\hline Building depreciation & 101 & $3.2 \pm 1.3$ & $0.6-7.3$ & 3.1 \\
\hline Purchased and homegrown feed & 101 & $35.6 \pm 10.0$ & $14.9-56.8$ & 35.7 \\
\hline Grazing & 96 & $7.0 \pm 3.7$ & $0-20.9$ & 6.4 \\
\hline Movement and transportation & 77 & $0.8 \pm 0.9$ & $0-5.9$ & 0.5 \\
\hline Breeding and fertility & 101 & $8.4 \pm 4.6$ & $0.7-21.7$ & 7.6 \\
\hline Water & 101 & $2.0 \pm 0.8$ & $0.8-4.5$ & 1.9 \\
\hline Vaccinations & 74 & $1.9 \pm 1.2$ & $0-5.3$ & 1.7 \\
\hline Worm control and ectoparasite treatment & 91 & $1.3 \pm 1.0$ & $0-5.3$ & 1.3 \\
\hline Disease and health treatments & 11 & $0.6 \pm 0.4$ & $0-1.6$ & 0.6 \\
\hline Slurry storage & 101 & $4.8 \pm 4.3$ & $0.6-23.0$ & 3.2 \\
\hline Electricity & 101 & $2.2 \pm 0.5$ & $1.1-4.6$ & 2.1 \\
\hline
\end{tabular}

${ }^{\mathrm{a}}$ There were 101 farms in the study but not all farms used all the potential inputs which were assessed.

\subsection{Labour}

The cost of labour per heifer from weaning to conception ranged from $£ 0.09$ to $£ 2.10$ per day with the total cost ranging from $£ 35.01$ for 433 days of rearing to $£ 1257.91$ for 630 days of rearing. The large difference in cost per day was most likely due to some farms having large numbers of staff compared to the number of heifers on farm therefore increasing the proportion of labour costs apportioned to the surviving heifers.

\subsection{Dry Feed}

The mean cost of homegrown or purchased feed (excluding grazed grass) for the period from weaning to conception was $£ 0.64 \pm 0.21$ per heifer per day (range $£ 0.21$ to $£ 1.15, \mathrm{n}=101$ ) with a median cost per day of $£ 0.57$. 
Most farms (98\%) fed their heifers for less than $£ 1.00$ a day during this period with only 2 farms paying more than $£ 1.00$ a day for feed. The mean cost of feed per heifer per day for the different calving patterns was $£ 0.51$ for spring calving herds, $£ 0.55$ for autumn calving herds, $£ 0.56$ for multi block calving herds and $£ 0.68$ for AYR calving herds. When the heifers were confined for longer during this development period, the cost per day of feeding tended to increase as shown in Figure 2.

\subsection{Turnout and Grazing}

Five farms did not graze heifers at all prior to their being confirmed in-calf by a veterinarian (4/5) or independent technician (scanner) (1/5). Of the farms which did turn heifers out to grass (96/101), the most common criteria for turnout were grass condition (46.5\%) followed by weather (38.6\%) and age of the heifer (27.7\%). The age that heifers were turned out for the first time and the amount of time spent at grass from weaning to conception was influenced strongly by the calving pattern. The overall mean age at turnout was $188.7 \pm 89.7 \mathrm{~d}$ : this varied from $129 \mathrm{~d}$ (spring calving), $178 \mathrm{~d}$ (AYR), $195 \mathrm{~d}$ (autumn calving) and 164 or $238 \mathrm{~d}$ (multi block calving).The most common month for turnout was April (47.9\%) with October being the usual month for rehousing (63.5\%).Overall, the mean number of days that heifers spent at grass was $196 \pm 53.4 \mathrm{~d}$ (range 91 to $426 \mathrm{~d}$, median $=182.5, \mathrm{n}=96$ ). Separated into calving pattern, spring born heifers spent on average $231 \mathrm{~d}$ at grass, autumn heifers $210 \mathrm{~d}$, multi block heifers $204 \mathrm{~d}$ and AYR born heifers were generally the lowest with a mean of $190 \mathrm{~d}$ although one farm out wintered their heifers. The mean cost of grazing per heifer was $£ 48.56 \pm 23.25$ (range $£ 5.50$ to $£ 118.46, \mathrm{n}=96$ ) with a median cost of $£ 44$.81.The cost per heifer per day spent grazing ranged from $£ 0.06$ to $£ 0.55$ with a mean of $£ 0.25 \pm 0.10$ (median $=£ 0.22, \mathrm{n}=96$ ).

\subsection{Breeding and Fertility}

The information on breeding strategies used, fertility data and associated costs is summarized in Table 2. The overall mean age at first breeding (AFB) was $15.7 \pm 2.1$ months (range 12 to 23.5 months) with a median AFB of 15 months and the mean age at conception was 16.7 months, range 12 to 23 months. Of the farms surveyed 20\% exclusively used natural service with a bull. Some farms (29\%) did not use a bull at all, with the remaining 51\% starting with AI then switching to a bull later. Only 11 farms used any sort of hormonal synchronization regime and this was nearly always associated with the use of sexed semen. Half of all farms surveyed used some sexed semen: only 3 used this exclusively with the remainder combining it with either conventional semen (15 farms), a bull (14 farms) or both (18 farms). Different farms were prepared to use between 1 and 8 straws in total (mean $2.5 \pm 1.6$, median $=1$ straw). The mean number of straws of sexed semen used was $1.6 \pm 0.8$ (range 1 to 5 straws, median $=1$ straw). For conventional semen the cost per straw was $£ 15.14 \pm 4.68$ (range $£ 7.00$ to $£ 30.00$, median $=£ 15.00, n=64$ ) whereas the mean cost of sexed semen was about twice as much per straw at $£ 30.02 \pm$ 7.68 (range $£ 15$ to $£ 54, n=48$ ), with a median cost per straw of $£ 30.00$. For farms using conventional semen

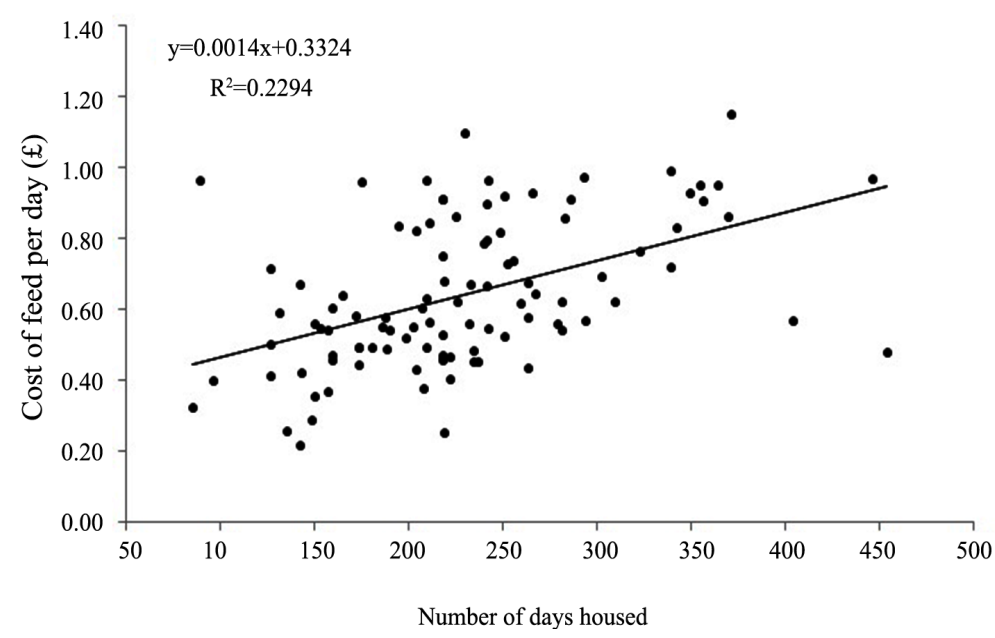

Figure 2. Regression analysis between the length of time heifers spent housed and the cost of feed per day. Each symbol represents one farm, $n=101$. 
Table 2. Summary data of the different breeding strategies used together with their associated fertility rates and costs.

\begin{tabular}{|c|c|c|c|c|c|c|c|}
\hline Breeding strategy & No. farms & $\begin{array}{l}\text { Hormone } \\
\text { treatments }\end{array}$ & AFS (d) & No. straws & FSCR (\%) & $\begin{array}{c}\text { Age at } \\
\text { conception (d) }\end{array}$ & $\begin{array}{r}\text { Cost per } \\
\text { heifer }(£)\end{array}$ \\
\hline Natural service only & 20 & 0 & 517 & 0 & Unknown $^{\dagger}$ & 553 & 32.31 \\
\hline $\begin{array}{l}\text { AI conventional semen } \\
\text { only no bull }\end{array}$ & 11 & 1 & 473 & $1-8$ & $\begin{array}{c}69 \pm 14.1 \\
(40 \%-90 \%)\end{array}$ & 504 & 51.92 \\
\hline $\begin{array}{l}\text { AI sexed semen } \\
\text { only no bull }\end{array}$ & 3 & 1 & 461 & $2-5$ & $\begin{array}{c}60 \pm 10 \\
(50 \%-70 \%)\end{array}$ & 507 & 119.80 \\
\hline $\begin{array}{l}\text { AI conventional and } \\
\text { sexed semen no bull }\end{array}$ & 15 & 0 & 505 & $1-5$ & $\begin{array}{c}65 \pm 17.6 \\
(4 \%-100 \%)\end{array}$ & 535 & 58.40 \\
\hline $\begin{array}{l}\text { AI conventional semen } \\
\text { only + bull }\end{array}$ & 20 & 0 & 455 & $1-3$ & $\begin{array}{c}66 \pm 10.5 \\
(4 \%-95 \%)\end{array}$ & 464 & 74.67 \\
\hline AI sexed semen only + bull & 14 & 8 & 461 & $1-3$ & $\begin{array}{c}51 \pm 17.3 \\
(2 \%-80 \%)\end{array}$ & 507 & 102.61 \\
\hline $\begin{array}{l}\text { AI conventional and } \\
\text { sexed semen }+ \text { bull }\end{array}$ & 18 & 1 & 454 & $1-7$ & $\begin{array}{c}55 \pm 15.0 \\
(4 \%-90 \%)\end{array}$ & 490 & 83.50 \\
\hline Total & 101 & 11 & & & & & \\
\hline
\end{tabular}

*Number of farms using hormone treatments; ${ }^{\dagger}$ Unknown—assigned 65\%; AFS—age at first service; FSCR—first service conception rate.

only, the mean first service conception rate was $66.3 \pm 8.8 \%$ (range $50 \%$ to $75 \%, \mathrm{n}=8$ ), median $70 \%$. The mean first service conception rate of farms using sexed semen only was numerically lower at $59.2 \pm 20.9 \%$ (range $21 \%$ to $80 \%$, median $=64 \%$ ).

The costs of using a bull on the farm ranged from $£ 1.07$ to $£ 14.50$ per heifer with a mean cost of $£ 5.02 \pm 2.91$ (median $=£ 4.27, n=59$ ). Those farms which bred all heifers by natural service only were also the latest to start serving their heifers at 17 months on average (range 13 to 23.5 months), so the animals did not conceive until 18 months. Their breeding costs of $£ 32.31$ per heifer were, however, considerably lower than on farms using AI. The farms using AI generally started the breeding process at a younger age of 15.4 months (range 12 to 21 months). In terms of fertility, the age at conception was lowest on farms using conventional semen with a bull to follow (15.2 months, $\mathrm{n}=20)$ and greatest on farms using a combination of conventional and sexed semen without a sweeper bull (17.6 months, $\mathrm{n}=15)$. The overall cost of breeding was lower on farms using conventional AI only without also keeping a bull (£51.92 per heifer). It was much higher on farms using sexed semen only with or without a bull (£102.61 and $£ 119.80$ respectively). Overall, the total cost of breeding and fertility (excluding the costs of farm labour) ranged from $£ 4.79$ to $£ 153.14$ per heifer with a mean total cost of $£ 58.47 \pm$ 29.93 (median £55.29, $\mathrm{n}=101$ ).

\subsection{Housing, Bedding and Slurry}

The mean amount of time that heifers were housed during this period was $229 \pm 74.5 \mathrm{~d}$ (range 72 to $454 \mathrm{~d}$ ) with a median time of $219 \mathrm{~d}$. On 31.7\% (32/101) of farms heifers were introduced to cubicle housing for the first time. The cost per day for bedding material ranged from $£ 0.01$ to $£ 0.60$ with a mean and median cost of $£ 0.16$ and $£ 0.13$ respectively. There were 66 (65.3\%) farms which disinfected youngstock housing when mucking out and rebedding. The mean cost per heifer spent on disinfection was $£ 2.58 \pm £ 6.23$ (range $£ 0.01$ to $£ 35.68$, median $=$ $£ 0.42, \mathrm{n}=66$ ). The cost of slurry storage and spreading soiled bedding ranged from $£ 0.01$ to $£ 0.47$ with a mean cost of $£ 0.08 \pm 0.08$ (median $=£ 0.05, n=101$ ). The large difference in cost per day was due to the amount of time the heifer spent at grass during this period with five farms permanently housing their youngstock during this development phase.

\subsection{Disease and Health Treatments}

A total of 11 farms treated their heifers for at least one health event during this period, with the most common infection treated being respiratory disease on six farms, two farms treated heifers for digital dermatitis, two farms treated heifers for eye infections and one farm had treated heifers for mastitis during the previous twelve month period. The cost per heifer per day for treatment ranged from $£ 0.05$ to $£ 0.52$ with a mean cost of $£ 0.33 \pm$ $0.16(\mathrm{n}=11$, median $=£ 0.35)$. 


\subsection{Vaccinations, Worming and Ectoparasite Treatment}

A total of 74 farms vaccinated their cattle for a particular health condition during this period. Of these farms, 28 administered vaccinations for more than one disease. The most common condition vaccinated against was bovine viral diarrhea (BVD) (61/74) followed by leptospirosis (54/74). The mean cost of vaccination per heifer was $£ 12.81 \pm 7.00$ (range $£ 0.80$ to $£ 30.56, n=74$ ) with a median cost of $£ 10.88$. Of the 96 farms that turned heifers out to grass, 5 farms did not use any type of worming or ectoparasite treatment prior to or after turnout or at rehousing. The mean cost per heifer of treatment for the farms that did use anthelmintics or ectoparasite specific treatments was $£ 9.00 \pm 7.02$ (range $£ 0.39$ to $£ 36.06, n=91$ ) with a median cost of $£ 9.60$. More than half of these farms (52.8\%) used more than one type of worming treatment on their heifers. The most commonly treated for endoparasite (42/91) was Dictyocaulus viviparous (lungworm). The number of farms treating heifers for flies was $53(58.2 \%)$ using a range of products from pour on combined worming and ectoparasite treatments to ear tags and garlic licks.

\subsection{Drinking Water and Electricity}

The mean cost per day per heifer for water consumption was $£ 0.03 \pm 0.01$ (range $£ 0.01$ to $£ 0.06$ ) with a median cost of consumption of $£ 0.03$. The mean cost of electricity per heifer was $£ 15.33 \pm 3.66$ (range $£ 8.45$ to $£ 41.64$ ) with a median cost of $£ 14.52$.

\subsection{Building Depreciation}

The cost of building depreciation per heifer for the development period from weaning to conception ranged from $£ 4.17$ to $£ 60.26$ with a mean cost of $£ 23.27 \pm 11.27$ (median $=£ 21.85$ ).

\subsection{Movement and Transportation}

Of the farms surveyed, 24 did not transport their heifers with a vehicle to another holding. Of the remaining farms, the mean return distance travelled was $7.6 \pm 11.1$ miles with a median distance of 5 miles (range 0.5 miles to 65 miles). The mean total cost of transport including once daily visits to the youngstock holding was $£ 5.84 \pm 8.43$ (range $£ 0.26$ to $£ 66.08, \mathrm{n}=77$ ) with a median transport cost of $£ 3.30$.

\subsection{Growth Monitoring}

Only 28 farms performed some method of growth monitoring of dairy heifers. Of these, 2 recorded heights of heifers during rearing whilst 26 recorded weight. The most frequent method (68\%) of deciding whether heifers were adequately grown before breeding was visual inspection, followed by use of weigh scales/crate (16\%) and weigh tape (7\%). Other methods included marks or a line on the crush or a wall, body condition score and a measuring stick. On 21/101 (20.8\%) of farms weight and/or height of heifers were verified to ensure optimal stage for reproduction before breeding was performed.

\subsection{Total Cost of Rearing from Weaning to Conception}

The mean total cost of rearing from weaning to conception was $£ 745.94 \pm 238.55$ (range $£ 295.32$ to $£ 1745.85$ ) with a median total cost of $£ 701.72$. The greatest contribution to total costs came from feed at $35.6 \%$ with the second and third highest expenses during this period being labour and bedding contributing $24.7 \%$ and $8.9 \%$ of total costs respectively (Figure 1). The combined feed cost including purchased and homegrown forage plus grazed grass ranged from $18.7 \%$ and $68.2 \%$ of the total cost of rearing with a mean contribution of $42.3 \% \pm 9.7$ (median $=41.9 \%$ ). The mean and median daily costs of rearing during this period were $£ 1.65 \pm 0.40$ and $£ 1.64$ respectively with total daily cost ranging from $£ 0.75$ to $£ 2.97$ per heifer.

The mean total cost of rearing from weaning to conception was lowest in spring calving herds (£506.32 \pm 173.76) and highest in AYR calving herds (£801.58 \pm 236.88$)$. Autumn calving herds had the second lowest mean total cost (£581.29 \pm 194.54$)$ followed by multi block calving herds (£695.65 \pm 140.93$)$ (Figure 3). As age at conception increased so did the cost of rearing, with heifers aged between 365 and 500 days (12 to 16.5 months) having the lowest mean total cost at $£ 619.16 \pm 143.50$. The mean total cost of rearing increased by approximately $32 \%$ for heifers conceiving between 16.5 and 18 months of age ( $£ 816.38 \pm 208.11$ ) and by $60 \%$ for 
heifers aged older than 18 months of age at conception (£988.01 \pm 293.70$)$ (Figure 4).

\subsection{Variables Influencing the Cost of Rearing from Weaning to Conception}

The main variables influencing the cost of rearing during this development period were age at breeding, age at conception, calving pattern and breed (Table 3). The remaining variables examined (region, herd size, culling rate, calving rate, stillbirth rate, first lactation yield, herd lactation yield and bovine TB status) suggested no association with the cost of rearing from weaning to conception. A test for correlation between age at breeding and age at conception produced a coefficient of 0.7984 indicating high correlation between the two variables therefore age at breeding was excluded from the multivariable model. The outcome of the final multivariable model was that age at conception, calving pattern and breed accounted for $51.1 \%$ of the variability in the cost of rearing from weaning to conception with an F $(9,91)$ statistic of $10.56(p<0.0001)$. The multivariable model predicted an increase in mean cost of rearing of $£ 2.26$ for each extra day age at conception. The predicted decrease in cost of rearing for autumn, multi-block and spring calving herds compared to AYR calving herds was £136.27, $£ 39.30$ and £184.46 respectively. Compared to Holstein herds, Friesian $\mathrm{x}$ and Jersey herds had a predicted de

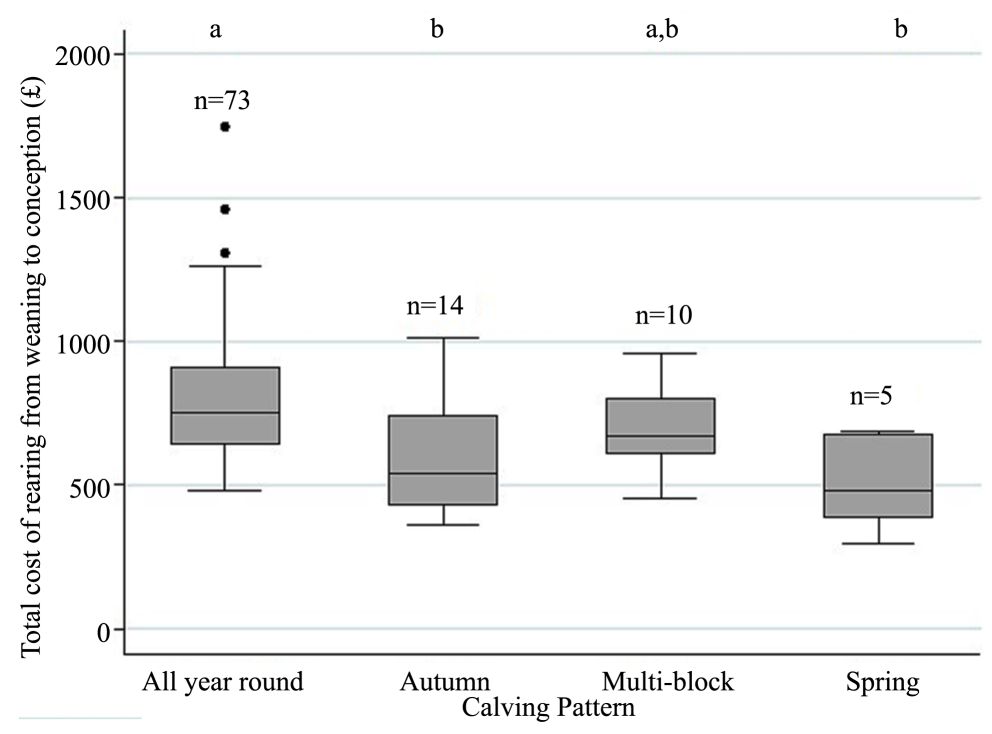

Figure 3. Box and whisker plot showing the total cost of rearing from weaning to conception for the four different calving patterns: $\mathrm{a}>\mathrm{b}, \mathrm{P}<0.05$.

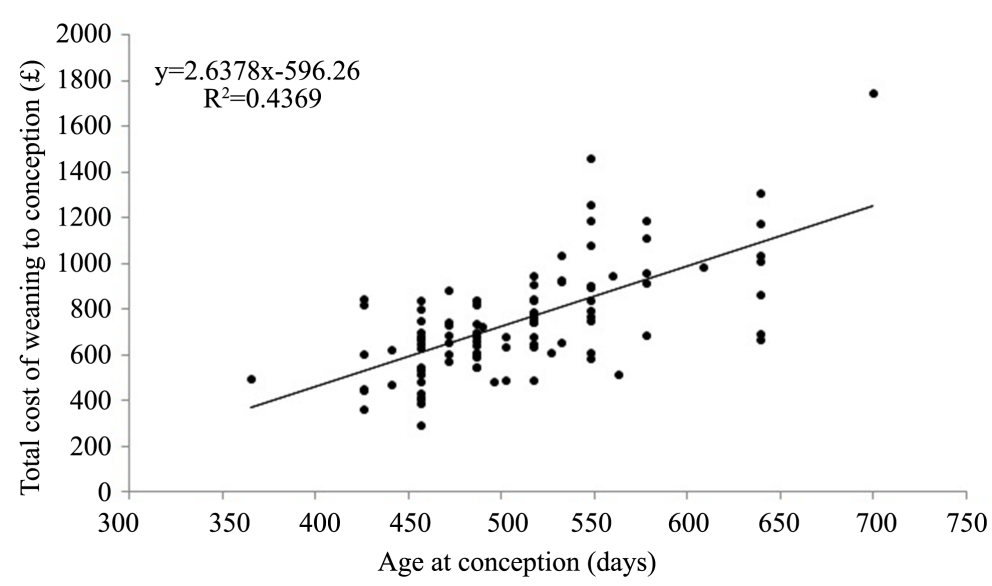

Figure 4. Regression analysis between the age at conception and the Total cost of rearing heifers from weaning to conception. Each symbol represents one farm, $\mathrm{n}=101$. 
crease in cost of rearing of $£ 37.67$ and $£ 30.87$ respectively while Holstein Friesian, Holstein $\mathrm{x}$ and other purebred herds had a predicted increase in the cost of rearing of $£ 47.44$, £88.11 and £84.23 respectively (Table 4).

\section{Discussion}

The major factor influencing the age at which heifers calve for the first time is the age at which they conceive. This in turn is controlled by the age at which the animals are first bred and the success of the breeding programme. On the farms studied here, the mean ages at first breeding and conception were $476 \mathrm{~d}$ (15.5 months) and $509 \mathrm{~d}$ (16.8 months). This is longer than ideal, as many animals would fail to achieve an AFC of 24 months, widely considered as being optimum for future productivity, fertility and survival, all of which are key determinants of profitability [1] [33] [34]. For heifers to be fertile they must first have reached puberty, and age at puberty is strongly influenced by nutrition and growth rate [35]. A number of previous on-farm studies have found evidence that some dairy heifers may be underfed, thus compromising their future performance [33] [36] [37]. Age at first calving and future productivity are also adversely influenced by calfhood diseases, notably bovine respiratory disease [33] [38]. We show here on UK farms that feed was the major expense, accounting for 36\% of the total cost of rearing heifers from weaning to conception. Delaying first calving increases the cost of rearing a heifer and decreases her future performance. It is vital that farmers understand both the importance of achieving good growth rates and the major factors influencing their rearing costs so that they can calve down well grown and healthy animals at the appropriate time.

Feed costs (excluding grazing) accounted for between $14.9 \%$ to $56.8 \%$ of the total cost from weaning to conception. When the cost of grazing was included, overall feed cost increased on average from $35.6 \%$ to $42.3 \%$ (range 18.7\% to 68.2\%). These percentages are much lower than those presented by Heinrichs et al. [39] and DARDNI [40] who calculated mean contributions of feed and grazing to cost of rearing from weaning to breeding of $75.7 \%$ (range $71.9 \%$ to $76.6 \%$ ) and $81.92 \%$ to $90.55 \%$ (depending on calving pattern and AFC) respectively. The differences between the studies may result from differences in cost of purchased feed, the length of

Table 3. The effect of different exposure variables on the total cost of rearing from weaning to conception assessed using one way ANOVA.

\begin{tabular}{ccccc}
\hline Variable & df & F & Prob $>$ F & Adj R $^{2}$ \\
\hline Age at breeding & 1.99 & 75.21 & $<0.0001$ & 0.4260 \\
Age at conception & 1.99 & 76.80 & $<0.0001$ & 0.4312 \\
Enterprise type & 1.99 & 1.74 & 0.1905 & 0.0073 \\
Calving pattern & 3.97 & 6.19 & 0.0007 & 0.1348 \\
Breed & 5.98 & 3.39 & 0.0073 & 0.1068 \\
Region & 9.91 & 1.66 & 0.1102 & 0.0561 \\
Herd size & 4.96 & 1.85 & 0.1256 & 0.0329 \\
Culling rate \% & 5.96 & 1.06 & 0.3856 & 0.0032 \\
Calving rate \% & 5.95 & 2.71 & 0.0247 & 0.0788 \\
Stillbirth rate \% & 4.96 & 1.31 & 0.2734 & 0.0121 \\
First lactation yield & 5.95 & 0.21 & 0.9575 & -0.0411 \\
Herd lactation yield & 5.95 & 0.40 & 0.8500 & -0.0311 \\
bTB status & 1.99 & 0.65 & 0.4231 & 0.0065 \\
Days at grass & 3.97 & 0.95 & 0.4181 & -0.0014
\end{tabular}

\footnotetext{
${ }^{\#}$ Age at breeding, age at first service; Age at conception; enterprise type, classification of farms on their organic status; calving pattern, season(s) when the majority of the herd calved; breed, predominant breed in the herd; herd size, number of cows in the milking herd including dry cows; culling rate, \% cows in the herd culled in the last 12 months; calving rate, \% cows in the herd calved in the last 12 months; stillbirth rate, \% calves born dead from the number of cows that calved in the last 12 months; first lactation and herd lactation yield, respective average yields (kg) from the most recent 305-day lactation records; bTB status, whether the farm was currently under movement restrictions.
} 
Table 4. Results of multivariable linear regression analysis of cost of rearing from weaning to conception and age at conception, enterprise type and calving pattern.

\begin{tabular}{|c|c|c|c|c|c|c|c|c|}
\hline Variable & & $\mathrm{n}$ & Coefficient & Std. Error & $\mathrm{t}$ & $P>|t|$ & \multicolumn{2}{|c|}{$95 \%$ CI } \\
\hline Age at conception & & 101 & 2.26 & 0.34 & 6.59 & $<0.0001$ & 1.58 & 2.94 \\
\hline \multirow[t]{6}{*}{ Enterprise type } & Baseline & 40 & & & Holst & & & \\
\hline & Holstein-Friesian & 29 & 57.44 & 43.14 & 1.10 & 0.274 & -3.26 & 133.13 \\
\hline & Holstein $\mathrm{x}$ & 13 & 88.11 & 59.52 & 1.48 & 0.142 & -30.12 & 206.34 \\
\hline & Friesian $\mathrm{x}$ & 4 & -37.67 & 105.51 & -0.36 & 0.722 & -247.26 & 171.71 \\
\hline & Other purebreds & 9 & 84.23 & 71.73 & 1.17 & 0.243 & -58.26 & 226.71 \\
\hline & Jersey & 6 & -30.87 & 78.73 & -0.39 & 0.696 & -187.26 & 125.51 \\
\hline \multirow[t]{4}{*}{ Calving pattern } & Baseline & 73 & \multicolumn{6}{|c|}{ All year round } \\
\hline & Autumn & 14 & -136.27 & 56.62 & -2.41 & 0.018 & -248.74 & -23.81 \\
\hline & Multi block & 10 & -39.30 & 61.76 & -0.64 & 0.526 & -161.98 & 83.37 \\
\hline & Spring & 5 & -184.46 & 94.24 & -1.96 & 0.053 & -371.66 & 2.73 \\
\hline
\end{tabular}

grazing period and average AFS. The DARDNI [40] study also only considers spring and autumn block calving herds. The percentage contribution of feed and grazing to overall cost of rearing for this period is also likely to differ due to the input costs which were included in the different studies.

The cost of grazing in the DARDNI [40] literature ranged from $£ 29$ to $£ 33$ per heifer in autumn born heifers and $£ 27$ to $£ 29$ in spring born heifers. In the present study the cost of grazing for autumn born heifers ranged from $£ 23$ to $£ 93$ and from $£ 20$ to $£ 53$ in spring born heifers. The difference in cost is likely due to the way in which cost of grazing was apportioned. In the DARDNI [40] study they stated specific age periods of grazing with effectively only one grazing season included. In this study, however, due to the location of the farms throughout the UK, the length of grazing season was highly variable. This accounted for the large differences between the ranges in cost of grazing.

The nutritional management impacts on the farmer's decision on when to start breeding as the heifers need to be of sufficient stature. In a recent survey of Dutch dairy farmers they said that they would start breeding at ages ranging from 13 to 18 months and the actual mean was 15.9 months, very similar to the 15.5 months reported here. Only a minority of farmers in either study actually measured their animals, so the size is normally judged by visual inspection. The actual age range recorded here was much wider, from 12 to 23.5 months. Two US studies similarly reported wide ranges in age at first breeding from 11 to 23 months [39] and 13 to 18 months [41] respectively. In practice this is likely to lead to some heifers calving down either too small or too fat, both of which can increase calving problems [42] [43]. In the study by Hultgren et al. [17] on Swedish Red Holstein cross heifers, the median time to breeding was 17.5 months and it was observed that the greater the time the heifers spent grazing, the greater the time to breeding and calving. A similar trend was found in our study. In contrast, whereas the Swedish study concluded that up to 5 months of grazing before first calving was more beneficial than zero grazing; our study found that zero grazed heifers were bred on average 3 weeks earlier than those which were grazed ( $432 \mathrm{~d}$ compared with $452 \mathrm{~d}$ ).

The cost of reproduction accounted for $8.4 \%$ (range $0.7 \%$ to $21.7 \%$ ) of the total cost of rearing from weaning to conception. The cost per heifer ranged from $£ 4.79$ to $£ 153.14$ with a mean total cost of $£ 58.47 \pm 29.93$ (median = £55.29). This is somewhat higher than a previous UK cost quoted by Promar International [44] at £48.00 and much higher than the DARDNI Farm Business Data [40] for Northern Ireland in which they give figures for AI, veterinary and miscellaneous of between $£ 33$ and $£ 38$ depending on season of birth and desired AFC. Neither of these reports provide detail of what is included in 'AI and other costs' so it is not known whether this accounted for the use of both sexed and unsexed semen and what conception rate was considered. In a study by Heinrichs et al. [39] on 44 dairy operations in Pennsylvania, United States, breeding accounted for on average $5.8 \%$ (range $1.2 \%$ to $7.5 \%$ ) of the combined costs for the periods from weaning to 6 months and 6 months to 
breeding. However, this would likely be lower if the study also included the cost of waste management, building depreciation and equipment maintenance and depreciation.

The farms surveyed adopted a wide variety of different breeding strategies with variable levels of success. The cheapest and probably easiest option was just to turn heifers out with a bull. This only cost £32.31 per heifer but the farmers who adopted this strategy also started breeding their heifers quite late, so their age at conception was higher at 18 months. This would have resulted in a later AFC and so increased overall rearing costs. The use of conventional semen was much less than that of sexed semen with median costs per straw of $£ 15$ and $£ 30$ respectively. The first service conception rate was also somewhat higher $(66 \% \mathrm{v} 60 \%)$ although the range was narrower with minimum figures of $50 \%$ and $21 \%$ respectively. This confirms much larger studies which have found that pregnancy rates in cattle with 2 million sexed sperm per insemination dose are about $80 \%$ of those with conventional semen at normal sperm doses [21]. Using sexed semen therefore increases the breeding costs significantly by around $£ 30$ to $£ 70$ per animal dependent on the strategy used. This extra outlay should, however, be recapped later due to the greater value of dairy heifers in comparison with bull calves. The use of sexed semen in the UK has increased rapidly in the UK over the past few years. This is to a large degree driven by welfare concerns over the fate of unwanted male calves on the part of a number of the supermarkets who are major buyers of milk. It has the additional benefit of increasing the rate of genetic progress from the herd when more dairy heifers are produced and decreasing the incidence of dystocia at first calving [45] [46].

Hultgren et al. [17] noted in their study of Swedish heifers that the most predominant diseases from 7 months of age to conception were diarrhoea, respiratory disease and ringworm. During data collection in our study it was observed that many heifers showed evidence of ringworm although few farmers were treating the condition and instead were relying on exposure to sunlight to aid the healing process. In the current study respiratory disease and digital dermatitis were the two most commonly treated infections during this development period. The total disease incidence rate was 8.9 per 100 animal-years which is lower than Hultgren et al. [17] who recorded an incidence rate of 14 per 100 animal-years. Disease was, however, probably under reported by the farms surveyed most likely due to the lack of reliable data recording with respect to administration of veterinary medicines.

The contribution of treating disease to overall costs of rearing from weaning to conception was $0.6 \%$ (range $0.0 \%$ and $1.6 \%$ ) with the mean cost of vaccination and worming contributing $1.9 \%$ and $1.3 \%$ respectively. If all three variable costs are combined as the cost of health treatments they accounted for between $0 \%$ and $8.4 \%$ of total cost of rearing during this period with a mean contribution of $2.7 \%$. In the study by Heinrichs et al. [39] on heifer production, the cost of "Health" included the cost of vaccinations, deworming treatments and disease treatment costs. In their study the mean contribution of health to cost of rearing during this period was $0.8 \%$ ranging from 0 to $2.4 \%$. However, the difference may be due to the fact that only the treatment cost of scours was included in their analysis and other more prevalent diseases during this period such as pneumonia were not considered. None of these figures account for the financial losses associated with death or poor growth rates due to disease. A previous UK study reported heifer mortality rates of $6.9 \%$ between 1 month of age and first breeding [2].

\section{Conclusion}

During the development period from weaning to conception heifers are often turned out to grass for the first time and are likely to be exposed to one or more types of internal parasites. This along with becoming accustomed to grazing for feed can result in a decrease in daily live weight gains if heifers are not managed efficiently. As a majority of farms move their youngstock to different holdings following weaning, good management can be a challenge. Reduced daily live weight gains and body stature can increase the age of onset of puberty and age of breeding. The cost of rearing during this period was associated most strongly with the age at breeding and age at conception. These should be managed through sound rearing and breeding practices during the period from weaning to conception to ensure that recommended daily live weight gains are maintained consistently and that high conception rates are achieved.

\section{Acknowledgements}

The authors thank all the dairy farmers who participated in the study. The work was co-funded by DairyCo and the BBSRC. The manuscript has been assigned the reference PPH_01045 by the RVC. 


\section{References}

[1] Wathes, D.C., Pollott, G.F., Johnson, K.F., Richardson, H. and Cooke, J.S. (2014) Heifer Fertility and Carry over Consequences for Life Time Production in Dairy and Beef Cattle. Animal, 8, 91-104. http://dx.doi.org/10.1017/S1751731114000755

[2] Brickell, J.S., McGowan, M.M., Pfeiffer, D.U. and Wathes, D.C. (2009) Mortality in Holstein-Friesian Calves and Replacement Heifers in Relation to Body Weight and IGF-I Concentration, on 19 Farms in England. Animal, 3, 11751182. http://dx.doi.org/10.1017/S175173110900456X

[3] Owens, F.N., Dubeski, P. and Hanson, C.F. (1993) Factors That Alter the Growth and Development of Ruminants. Journal of Animal Science, 71, 3138-3150.

[4] Le Cozler, Y., Peyraud, J.L. and Troccon, J.L. (2009) Effect of Feeding Regime, Growth Intensity and Age at First Insemination on Performances and Longevity of Holstein Heifers Born during Autumn. Livestock Science, 124, 72-81. http://dx.doi.org/10.1016/j.livsci.2008.12.011

[5] Desjardins, C. and Hafs, H.D. (1969) Maturation of Bovine Female Genitalia from Puberty through Puberty. Journal of Animal Science, 28, 502-508.

[6] Meyer, M.J., Capuco, A.V., Ross, D.A., Lintault, L.M. and Van Amburgh, M.E. (2006) Developmental and Nutritional Regulation of the Prepubertal Bovine Mammary Gland: II. Epithelial Cell Proliferation, Parenchymal Accretion Rate, and Allometric Growth. Journal of Dairy Science, 89, 4298-4304. http://dx.doi.org/10.3168/jds.S0022-0302(06)72476-6

[7] Moallem, U., Werner, D., Lehrer, H., Zachut, M., Livshitz, L., Yakoby, S. and Shamay, A. (2010) Long-Term Effects of ad Libitum Whole Milk Prior to Weaning and Prepubertal Protein Supplementation on Skeletal Growth Rate and First-Lactation Milk Production. Journal of Dairy Science, 93, 2639-2650. http://dx.doi.org/10.3168/jds.2009-3007

[8] Khan, M.A., Weary, D.M. and von Keyserlingk, M.A.G. (2011) Hay Intake Improves Performance and Rumen Development of Calves Fed Higher Quantities of Milk. Journal of Dairy Science, 94, 3547-3553. http://dx.doi.org/10.3168/jds.2010-3871

[9] Sejrsen, K. and Purup, S. (1997) Influence of Prepubertal Feeding Level on Milk Yield Potential of Dairy Heifers: A Review. Journal of Dairy Science, 75, 828-835.

[10] Sejrsen, K., Purup, S., Vestergaard, M. and Foldager, J. (2000) High Body Weight Gain and Reduced Bovine Mammary Growth: Physiological Basis and Implications for Milk Yield Potential. Domestic Animal Endocrinology, 19, 93-104. http://dx.doi.org/10.1016/s0739-7240(00)00070-9

[11] Zanton, G.I. and Heinrichs, A.J. (2005) Meta-Analysis to Assess Effects of Prepubertal Average Daily Gain of Holstein Heifers on First-Lactation Production. Journal of Dairy Science, 88, 3860-3867. http://dx.doi.org/10.3168/jds.S0022-0302(05)73071-X

[12] Margerison, J. and Downey, N. (2005) Guidelines for Optimal Dairy Heifer Rearing and Herd Performance. In: Garnsworthy, P.C., Ed., Calf and Heifer Rearing: Principles of Rearing the Modern Dairy Heifer from Calf to Calving, Nottingham University Press, Nottingham, 307-338.

[13] Bach, A. and Ahedo, J. (2008) Record Keeping and Economics of Dairy Heifers. Veterinary Clinics of North America: Food Animal Practice, 24, 117-138. http://dx.doi.org/10.1016/j.cvfa.2007.10.001

[14] Moran, C., Quirke, J.F. and Roche, J.F. (1989) Puberty in Heifers: A Review. Animal Reproduction Science, 18, 167-182. http://dx.doi.org/10.1016/0378-4320(89)90019-5

[15] Brickell, J.S., Bourne, N., McGowan, M.M. and Wathes, D.C. (2009) Effect of Growth and Development during the Rearing Period on the Subsequent Fertility of Nulliparous Holstein-Friesian Heifers. Theriogenology, 72, 408-416. http://dx.doi.org/10.1016/j.theriogenology.2009.03.015

[16] Kuhn, M.T., Hutchison, J.L. and Wiggans, G.R. (2006) Characterization of Holstein Fertility in the United States. Journal of Dairy Science, 89, 4907-4920. http://dx.doi.org/10.3168/jds.S0022-0302(06)72541-3

[17] Hultgren, J., Svensson, C., Maizon, D.O. and Oltenacu, P.A. (2008) Rearing Conditions, Morbidity and Breeding Performance in Dairy Heifers in Southwest Sweden. Preventive Veterinary Medicine, 87, 244-260. http://dx.doi.org/10.1016/j.prevetmed.2008.04.003

[18] Stevenson, J.S., Smith, M.W., Jaeger, J.R., Corah, L.R. and LeFever, D.G. (1996) Detection of Estrus by Visual Observation and Radiotelemetry in Peripubertal Estrus-Synchronized Beef Heifers. Journal of Animal Science, 74, 739735.

[19] Mallory, D.A., Nash, J.M., Ellersieck, M.R., Smith, M.F. and Patterson, D.J. (2011) Comparison of Long-Term Progestin-Based Protocols to Synchronize Estrus before Fixed-Time Artificial Insemination in Beef Heifers. Journal of Animal Science, 89, 1358-1365. http://dx.doi.org/10.2527/jas.2010-3694

[20] Mallory, D.A., Lock, S.L., Woods, D.C., Poock, S.E. and Patterson, D.J. (2013) Comparison of Sex-Sorted and Con- 
ventional Semen within a Fixed-Time Artificial Insemination Protocol Designed for Dairy Heifers. Journal of Dairy Science, 96, 854-856. http://dx.doi.org/10.3168/jds.2012-5850

[21] Seidel, G.E. (2014) Update on Sexed Semen Technology in Cattle. Animal, 8, 160-164. http://dx.doi.org/10.1017/S1751731114000202

[22] Coop, R.L. and Holmes, P.H. (1996) Nutrition and Parasite Infection. International Journal for Parasitology, 26, 951-962. http://dx.doi.org/10.1016/S0020-7519(96)80070-1

[23] Forbes, A.B., Huckle, C.A., Gibb, M.J., Rook, A.J. and Nuthall, R. (2000) Evaluation of the Effects of Nematode Parasitism on Grazing Behaviour, Herbage Intake and Growth in Young Grazing Cattle. Veterinary Parasitology, 90, 111-118. http://dx.doi.org/10.1016/S0304-4017(00)00218-1

[24] Elsener, J., Villeneuve, A. and Côteaux, D. (2001) Evaluation of a Strategic Deworming Program in Dairy Heifers in Quebec Based on the Use of Moxidectin, an Endectocide with a Long Persistency. The Canadian Veterinary Journal, 42, 38-44.

[25] Boulton, A.C., Rushton, J. and Wathes, D.C. (2015) A Study of Dairy Heifer Rearing Practices from Birth to Weaning and Their Associated Costs on UK Dairy Farms. Open Journal of Animal Sciences, 5, 185-197. http://dx.doi.org/10.4236/ojas.2015.52021

[26] Vasseur, E., Rushen, J., de Passillé, A.M., Lefebvre, D. and Pellerin, D. (2010) A Canadian Intervention Strategy to Encourage Changes in Calves and Heifers Management to Improve Welfare in Dairy Farms. Journal of Dairy Science, 93, 4414-4426. http://dx.doi.org/10.3168/jds.2009-2586

[27] Jousan, F.D., Drost, M. and Hansen, P.J. (2005) Factors Associated with Early and Mid-to-Late Fetal Loss in Lactating and Non-Lactating Holstein Cattle in a Hot Climate. Journal of Animal Science, 83, 1017-1022.

[28] Agro Business Consultants Ltd. (2013) The Agricultural Budgeting and Costing Book. Melton Mowbray, Leicestershire.

[29] DairyCo. (2011) Grassland Management Improvement Programme. Agriculture and Horticulture Development Board, Stoneleigh Park, Warwickshire.

[30] DairyCo. (2012) PD+ Managing Heifer Rearing. http://www.dairyco.org.uk/resources-library/technical-information/fertility/pdplus-section-10-managing-heifer-rearing/ \#.UxTkmON_slI

[31] Healy, A.A., House, J.K. and Thomson, P.C. (2013) Artificial Insemination Field Data on the Use of Sexed and Conventional Semen in Nulliparous Holstein Heifers. Journal of Dairy Science, 96, 1905-1914. http://dx.doi.org/10.3168/jds.2012-5465

[32] Dohoo, I., Martin, W. and Stryhn, H. (2009) Veterinary Epidemiologic Research. VER Inc., Prince Edward Island.

[33] Bach, A. (2011) Associations between Several Aspects of Heifer Development and Dairy Cow Survivability to Second Lactation. Journal of Dairy Science, 94, 1052-1057. http://dx.doi.org/10.3168/jds.2010-3633

[34] Evans, R.D., Wallace, M., Shalloo, L., Garrick, D.J. and Dillon, P. (2006) Financial Implications of Recent Declines in Reproduction and Survival of Holstein Friesian Cows in Spring-Calving Irish Dairy Herds. Agricultural Systems, 89, 165-183. http://dx.doi.org/10.1016/j.agsy.2005.08.008

[35] Gasser, C.L. (2013) Joint Alpharma-Beef Species Symposium: Considerations on Puberty in Replacement Beef Heifers. Journal of Animal Science, 91, 1336-1340. http://dx.doi.org/10.2527/jas.2012-6008

[36] Brickell, J.S. and Wathes, D.C. (2011) A Descriptive Study of the Survival of Holstein-Friesian Heifers through to Third Calving on English Dairy Farms. Journal of Dairy Science, 94, 1831-1838. http://dx.doi.org/10.3168/jds.2010-3710

[37] Van Amburgh, M.E., Soberon, F., Karzses, J. and Everett, R.W. (2011) Taking the Long View: Treat Them Nice as Babies and They Will Be Better Adults. Proceedings of Western Dairy Management Conference, Reno, 9-11 March 2011, 141-157.

[38] Correa, M.T., Curtis, C.R., Erb, H.N. and White, M.E. (1988) Effect of Calfhood Morbidity on Age at First Calving in New York Holstein Herds. Preventive Veterinary Medicine, 6, 253-262. http://dx.doi.org/10.1016/0167-5877(88)90037-2

[39] Heinrichs, A.J., Jones, C.M., Gray, S.M., Heinrichs, P.A., Cornelisse, S.A. and Goodling, R.C. (2013) Identifying Efficient Dairy Heifer Producers Using Production Costs and Data Envelopment Analysis. Journal of Dairy Science, 96, 1-8. http://dx.doi.org/10.3168/jds.2012-6488

[40] Department of Agriculture and Rural Development North Ireland (DARDNI) (2014) Farm Business Data 2014. http://www.dardni.gov.uk/farm_business_data_2014.pdf

[41] Gabler, M.T., Tozer, P.R. and Heinrichs, A.J. (2000) Development of a Cost Analysis Spreadsheet for Calculating the Costs to Raise a Replacement Dairy Heifer. Journal of Dairy Science, 83, 1104-1109. 
http://dx.doi.org/10.3168/jds.S0022-0302(00)74975-7

[42] Hansen, M. (2004) Quantitative Genetic Analysis of Mortality in Danish Holstein Calves. Ph.D. Dissertation, The Royal Veterinary and Agricultural University, Frederiksberg.

[43] Cooke, J.S., Cheng, Z., Bourne, N.E. and Wathes, D.C. (2013) Associations between Growth Rates, Age at First Calving and Subsequent Fertility, Milk Production and Survival in Holstein-Friesian Heifers. Open Journal of Animal Sciences, 3, 1-12. http://dx.doi.org/10.4236/ojas.2013.31001

[44] Promar International (2011) What Are Heifer Replacements Really Costing You? http://www.milkminder.co.uk/news/Heifer\%20costs.PDF

[45] De Vries, A., Overton, M., Fetrow, J., Leslie, K., Eicker, S. and Rogers, G. (2008) Exploring the Impact of Sexed Semen on the Structure of the Dairy Industry. Journal of Dairy Science, 91, 847-856. http://dx.doi.org/10.3168/jds.2007-0536

[46] Schuenemann, G.M., Nieto, I., Bas, S., Galvão, K.N. and Workman, J. (2011) Assessment of Calving Progress and Reference Times for Obstetric Intervention during Dystocia in Holstein Dairy Cows. Journal of Dairy Science, 94, 5494-5501. http://dx.doi.org/10.3168/jds.2011-4436 